\title{
Health Education In Bophuthatswana
}

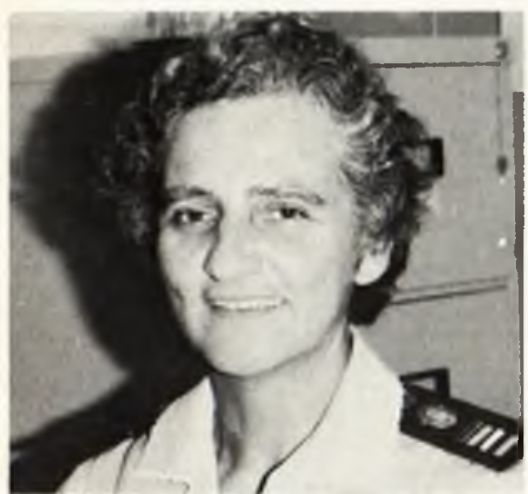

Mrs B. Robertson

\author{
B. Robertson, B.Cur. (I. et A.) \\ Chief Nursing Officer \\ and
}
A. N. Lekgetha, D.N.A., P.H.N. Deputy Chief Nursing Officer

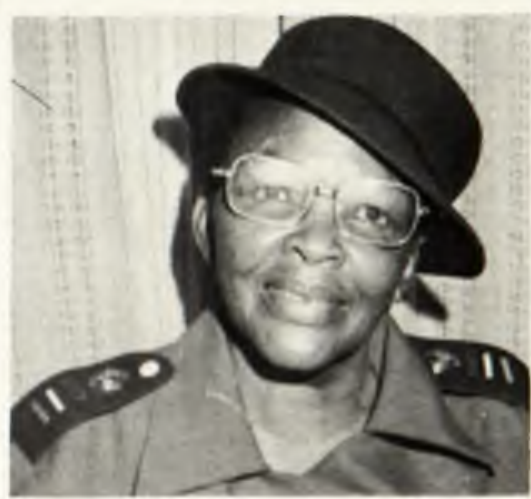

Mrs A. N. Lekgetha

\section{OPSOMMING}

Van die bestaan van die mens af is gesondheidsvoorligting op die een of ander wyse beoefen. Hierdie vorm van gesondheidsvoorligting wat deel van 'n kultuur vorm om homself te bly handhaaf, kan miskien nie met die moderne omskrywing van gesondheidsvoorligting vergelyk word nie. Hulle is egter stewig vasgelê en maak verandering moeilik.

Die Departement van Gesondheid en Maatskaplike Welsyn het in April 1975 tot stand gekom. Dit het 'n model van omvattende gesondheidsorg aanvaar, maar nie 'n bepaalde beleid oor gesondheidsvoorligting gehad nie. Gesondheidswerkers sou met die bestaande programme voortgaan en personeel aanmoedig om meer belangstelling in die aspek te toon. Gemeenskapsvoorligting en immuniseringsdienste - 'n afdeling binne die departement wat die werksaamhede van die gesondheidshelpers beheer het, het die organisasie van gesondheidsvoorligtingswerksaamhede as een van hulle doelstellings gehad.

$\mathbf{F}$ ORMS of health education have been practised for as long as man has been in existence. These forms of health education that are part of a culture to ensure its survival may not be comparable with a modern-day definition of health education. They are, nevertheless, firmly entrenched and make change difficult.

Traditional 'health education' in Bophuthatswana was normally passed on by the mother-in-law and had to be obeyed. Women belonging to the traditional tribal councils were responsible for the establishment of and adherence to village norms. This education was aimed at teaching people what to do to provide themselves with fortification and protection against witches and evil spirits who could cause mishap, illness or other ill-omens. During times of family crisis e.g. the birth of a baby, marriage, illness, accident or death, the family was especially vulnerable and needed protection. A horn containing charms was hung in the house and its ability to protect the family and house was especially respected.

Today many of these preventive measures are still being practised, although among the well-educated families it is done secretly. Charms are given by witchdoctors for protection and fortification and may be worn, placed in a motor car. in the area where food is cooked or in a special room. Adherence to these practices is often reinforced in the religious teachings of the separatist churches. Dutch patent medicines, especially the burning of Duiwels-struik have special protection powers to prevent cross-infection.

Western medicine of which Health Education is a part, is accepted. There is a saying that a person is an elephant and therefore he takes all herbs. This means that both the traditional health education teachings and those belonging to scientific medicine are acceptable.

Unfortunately the message of some of the health educators has not always been well understood. Kwashiorkor is called 'papsiekte' and the belief is growing that porridge is bad and should not be used. It is being replaced by potatoes and rice Meat is necessary to prevent kwashiorkor. An unnatural emphasis has been placed on the importance of meat, to the neglect of the use of other proteins that are cheaper and as effective. Lists of good foods that make for healthy living are given with no instruction on how to plan a diet. Potato salad with mayonnaise. fried potatoes and mashed potatoes and beans may be served at the same meal together with "Ting" (sour sorghum porridge). 
Clinic services have only been considered suitable for the poorer classes. Valuable information given at the clinic goes unheeded as it does not reach the community leaders. Many educated people would consider it beneath their dignity to visit a clinic for advice.

\section{Health Education in Bophuthatswana before the estab- lishment of the Department of Health and Social Welfare}

With her knowledge of some of the traditional practices mentioned above the district nurse sought to spread sound health education knowledge to both the urban and rural people. This was done informally through face-to-face contact with the patient or formally through lectures given to groups of mothers, community members or waiting patients. Although not scientifically planned or controlled it was not entirely unsuccessful. The number of children with diphtheria or whooping cough began to decrease. antenatal attendances and hospital or clinic deliveries increased. The communities began to appreciate the importance and benefits to them of good mother-and child-care. Hospital nurses isolated from their communities, involved in curative services. were not so aware of the need for health education. Nevertheless much knowledge was passed on during the course of giving patient care.

District nurses also encouraged community development projects. Tribal mothers" groups were started. These mothers together with the nurse worked together to build dams, creches and maternity depots.

\section{The New Department}

The Department of Health and Social Welfare was established in April 1975. It adopted a comprehensive health care model but it did not have a specific policy statement on health education. Health workers were to continue with their existing programmes and to encourage staff to be more interested in this aspect. Community education and immunization services, a division within the department which controlled the activities of the health assistants had the organisation of health education activities as one of their goals. Among the subjects to be included were: family planning, dietetics. environmental hygiene and mental hygiene.

This division also had in its control a mobile health education unit which travelled around Bophuthatswana assisting with general health education programmes, health needs and health exhibitions.

The division clearly stated that it did not "own" health education. but that its objective was to co-operate towards building a healthy nation. It further saw its function as that of a watchdog to see that expensive unscientifically planned programmes were not undertaken. This group has disseminated a large amount of health knowledge and many booklets and pamphlets have been distributed.

\section{Survey of Health Education done by Regional Hospitals in 1977}

The nursing division had no real knowledge of what role health education played in the nursing services. A questionnaire originally drawn up by the Department of Health.
Pretoria, was sent out to the matrons of 9 (nine) regional hospitals.

The questions asked were as follows:

Question 1: What were the health education priorities for 1977? Why were the subjects chosen and who were the target groups?

Question 2: What health education projects were undertaken? Information was to be supplied on the aims of the projects, the methods used, the materials produced or used, the personnel involved, the geographical areas covered, the target group numbers involved. the approximate costs and the results.

Question 3: What health education materials and/or facilities are available?

Question 4: What training was provided for the workers utilized for health education?

Question 5: What problems were encountered with health education?

Question 6: What suggestions have you to make with regard to health education? Six out of the 9 regions responded and 16 completed questionnaires were received from hospitals and clinics. The questionnaire was not well understood by all, especially by nurses at clinic level. This made the analysis of the information very difficult. Some of the most significant points are set out.

Question I: Priorities for health education naturally varied from area to area and covered all aspects of nutrition, tuberculosis, typhoid fever, diarrhoea and the problem of babies born without the help of the midwife. The reason for choosing their priorities was not understood and in many instances the purposes of the health education were given. Only two substantiated their reason for choosing their priority by indicating the high incidence of the disease in the hospital or region

Question 2: This question was again not understood. Individual lecture subjects were given as projects undertaken. Demonstrations were given and visual aids used. Numbers contacted were varied from small groups to larger communities. Costs were not known and the evaluation of results was based on general suppositions e.g. aims achieved. In some instances no evaluation was done and in all instances no defined criteria were used.

Question 3: A variety of visual aids which included flannelgraphs. poster films, and charts were available. The hospitals had access to more sophisticated materials than the clinics. Question 4: No training was given to workers doing health education. Lectures given by student nurses in training were supervised by the teaching unit.

Question 5: Many problems were encountered: some of the main ones are listed below:

- people won't change

- ignorance

- lack of money for health education - poor roads - shortage of staff

- those who don't attend clinics are not reached

- insufficient supply of visual aids

- antenatal cases don't come early enough 
- language used in the pamphlets is unsuitable

- lack of enthusiasm

- no time

- more beer halls and bottle stalls than clinics

- more literature required for distribution

- voluntary workers want to be paid

- only the very young, scholars and the aged are contacted, the young adult group are missed.

Question 6: A wide range of suggestions were given which included:

- running feeding schemes

- getting help from milk companies

- legalizing schoolfeeding schemes

- giving lectures at general meeting places e.g. the Magistrate's court

- stimulating community involvement

- holding competitions

- training of qualified persons as health educators who can draw up programmes and supervise work

- providing health education facilities and materials

- providing more staff

From the information gained it can be deducted that:

- health knowledge is being spread

- health education programmes are not scientifically planned, implemented or evaluated

- except for what is given in basic training health workers are not trained for this task

- many problems have been encountered in doing health education

- valuable suggestions for improvements or change have been made.

Much more emphasis must be given to health education. Guidance and expertise are needed at regional level.

\section{Formulation of a Health Education Policy for Bophuthatswana}

The department felt the need for a policy on health education to be formulated so that it could be effectively integrated into all aspects of health work within the comprehensive care system. It was recognised that many of the common health problems were preventable and much chronic ill health could be avoided if people were to accept the concept of health as a valued asset.

Aś it did not have sufficient expertise the department asked the South African National Council for Health Education to assist them with proposals for planning and policy-making. The proposals made used an integrative approach based on the compromise model recommended by the World Health Organisation.

The following principles were used in formulating the proposals:

- every health worker should be a health educator

- a core of professional health workers, that is, doctors, nurses and a health inspector should undergo postgraduate training in health education.

- health education should be based on sound educational principles
- a medical doctor should preferably lead the team

- community development and participation should be promoted

The plan envisages the establishment of a national health education unit which would provide the following service:

1. The provision of an overall policy for the organisation of the health education services.

2. The initiation of special community education projects. These projects would deal with the most important environmental, personal and preventive health problems.

3. The organisation of refresher courses and in-service training for health workers.

4. The establishment of an audio-visual centre.

5. Liaison with the mass media.

6. The evaluation of the health education field services

7. The execution of relevant health education research.

8. A plan for health education in the peripheral clinics.

Professional staff who have specialized in health education were not available to establish such a unit. It was felt that interested people should first be found and sent for training. It was further decided that a pilot scheme based on the principles previously described should be undertaken in one of the regional areas. This would enable the department to evaluate the effectiveness of such an approach and to iron out problems before policy and a national unit were established.

\section{Pilot Project}

A pilot project is being commenced this year. The area chosen had already done considerable groundwork and had sufficient staff interested in being involved. Two committees have been set up. These are:

1. An Advisory Committee; consisting of personnel from the Department of Health \& Social Welfare and the region.

2. A pilot project committee; This consists of:

- a doctor as teamleader. He will devote half of his time to health education.

- a senior sister who will also devote half of her time to the project.

- a health inspector

- a health assistant

This committee and other team members who will be involved will be responsible to train themselves and to call in specialists from outside to come and help.

\section{General Objectives}

The general ofjectives have been set by the Advisory Committee. These are:

- to assess the health needs of the local community

- to establish priorities within the budget and what can be done with available resources

- to institute a programme of health education.

The specific objectives will be established by the pilot committee. The committee will be involved in establishing liaison with the community.

Co-operation with the Departments of Agriculture and Education will also need to be established as many of their 
personnel are directly or indirectly involved in health education.

The committee will design a plan that is scientifically based and that can be evaluated for quality as well as quantity. The committee will consult with resource persons in the Republic of South Africa where necessary.

They will decide on a common approach to problemsolving and will plan the training programme necessary for those to be involved in the project. A budget will be drawn up and will provide for needs for additional staff including secretarial help, equipment and resource books. The project will be evaluated in two years time.

\section{Health education in the rest of Bophuthatswana}

The other regions will continue with their programmes as previously organised. Radio talks by the Radio Doctor, Koko Nurse Alina and the health assistants will be broadcast. The pilot committee will be asked to handle any correspondence resulting from these talks. An increased interest in health education will be encouraged. A two-week health education module is included in the training of advanced clinical care nurses; 18 are trained every year.

\section{Conclusion}

A beginning has been made to establish a soundly based health education programme that is integrated into all aspects of health care. A long road lies ahead. Goals are long-term and will require change and the training of doctors, nurses, health inspectors and health assistants. Policy will have to be established and funds budgeted for this work. The results that can be achieyed are a community that will take responsibility for its own health, a better use of limited resources and a reduction in the incidence of some common preventable diseases.

\section{ACKNOWLEDGEMENTS}

I wish to acknowledge with thanks the permission granted by the Secretary of the Department of Health and Social Welfare to write the article and for permission to use information from departmental reports on health education. 